\title{
Development of Value Added Food Products with Incorporation of Colocasia Leaves (Colocasia esculenta)
}

\author{
Pratibha Thombare* $^{*}$ and Farooqui H. Farzana \\ Department of Food Science and Nutrition, College of Community Science, VNMKV \\ Parbhani-431402, Maharashtra, India \\ *Corresponding author
}

\section{A B S T R A C T}

\begin{tabular}{|l|}
\hline K e y w o r d s \\
$\begin{array}{l}\text { Coloasia esculent, } \\
\text { organoleptic evaluation, } \\
\text { Nutrient content, Shelf } \\
\text { life }\end{array}$ \\
\hline Article Info \\
\hline $\begin{array}{l}\text { Accepted: } \\
\text { 22 October } 2018 \\
\text { Available Online: } \\
\text { 10 November } 2018\end{array}$ \\
\hline
\end{tabular}

An investigation entitled "Development of value added food products with incorporation of colocasia leaves (Colocasia esculenta)" was under taken to develop various value added products. For the preparation of products with fresh colocasia leaves, the colocasia leaves were boiled and then added in the products with different variation. The products prepared with the fresh colocasia leaves were colocasia dhapata, colocasia masala vada. Prepared products were evaluated for sensory characteristics and highly accepted products were analyzed for nutrient content and storage study was also carried out. Results indicated that 10 per cent fresh colocasia leaves can be incorporated in colocasia dhapata, colocasia masala vada. It is found that colocasia masala vada can be stored for three days, colocasia dhapata for four days can be stored in acceptable condition in aluminium foil. Colocasia leaves are rich in calcium so the calcium content of the products will be increased and will be useful to combat calcium deficiency. Colocasia leaves are also rich in minerals like iron, copper, zinc and manganese so the addition of colocasia leaves will be helpful to cure micronutrient deficiencies.

\section{Introduction}

Colocasia is an important food crop of West Africa and Oceania. Origin of colocasia is South or South -East Asia. It is an herbaceous plant that grows to the height 1-2m. Colocasia leaves are also called as taro. The leaves and the corn are the edible part that is easily digestible.

Colocasia is a member of the Araceae family is an ancient crop grown throughout the humid tropics for its edible corns, cormels and leaves, as well as for other traditional uses
(Anju Rani et al., 2017). Cocoyam is a wellknown food plant which has a long history of cultivation. Its corns are important source of starch. The corns can be cut up and boiled in curries or fried to make crispy chips. The leaf stalk and matured leaves are also eaten as vegetables (Odedeji et al., 2014).

Fresh colocasia leaves (green variety) contain moisture $82.7 \mathrm{~g}$, protein $3.9 \mathrm{~g}$, fat $1.5 \mathrm{~g}$, minerals $2.5 \mathrm{~g}$, crude fiber $2.9 \mathrm{~g}$, carbohydrate $6.8 \mathrm{~g}$, energy $56 \mathrm{Kcal}$, calcium $227 \mathrm{mg}$, phosphorus $82 \mathrm{mg}$, iron $10 \mathrm{mg}$, copper $0.18 \mathrm{mg}$ (Gopalan et al., 1989). 
The fresh leaves of colocasia had moisture content of 83.4 to 87.0 percent with a total soluble solid (TSS) varying from $1.8-2^{\circ} \mathrm{B}$. Drying of fresh leaves without any pretreatment and in the absence of blanching resulted in undesirable colour changes from green which is a typical of fresh vegetable to olive brown or brown discoloration. Blanching of colocasia leaves in water for 10 seconds or in alkali like sodium bicarbonate $(0.1 \%)$ resulted in superior product with unlike the steam blanched or unblanched leaves by showing minimal loss of green colour as reflected in chlorophyll content and nutritional characteristics (Kausal et al., 2013).

Fresh leaves of colocasia had a phenol content $(28.33-30.53 \mu \mathrm{g} / 100 \mathrm{~g})$ and ascorbic acid (19.5$22.7 \mathrm{mg}$ ) thus highlighting its antioxidant activity. The fibre and ash content of colocasia leaves ranged between 0.87-1.47 and 10.6$12.2 \%$ respectively. The $\mathrm{pH}$ of the fresh colocasia leaves was recorded as 7.70-7.76, thus slight change in its $\mathrm{pH}$ may result in colour change or chlorophyll degradation (Kaushal et al., 2013). Leaves of colocasia are cooked and eaten as vegetable and are said to contain $B$-carotene, iron and folic acid which protects against anaemia and are important source of proteins and vitamins just like the corns of cocoyam. The main nutrient supplied by cocoyam, is as with other roots and tubers is dietary energy provided by carbohydrates.

Regularly consuming freshly cooked colocasia, one is sure to keep off dangerous disease like cancer. This is due to the presence of vitamin $\mathrm{C}$ in them. Vitamin $\mathrm{C}$ is a protective and powerful antioxidant that can prevent common ailments like cold, cough certain cancers. This vitamin is also required for the growth of strong connective tissues like tendons, cartilage and ligaments. It improves the overall immunity level of the body, speeds the healing process of injuries, and assists in the synthesis of neurotransmitters and hormones. The leaves of colocasia contain enormous amounts of phenolic and carotenoid compounds, which tend to exhibit potent antioxidant properties. Both these chemical compounds help the body to fight free radicals and takes care of the cells from further damage and oxidative stress.

The main problem in the consumption of the leaves of colocasiais the presence of antinutritional factors. These factors may have adverse effects on health through inhibition of protein digestion, growth, iron and zinc absorption. However, all parts of the raw colocasia plant are known to contain oxalate, which must be destroyed by thorough cooking before eating. Soluble oxalates were $74 \%$ of the total oxalate content (Oscarsson K. V. and Savage G. P (2007). The presence of oxalate causes sharp irritation and burning sensation in the mouth and throat when tubers or leaves are eaten, but when boiled reduces the oxalate content (Noonia and Savage, 1999) and thus eliminate or reduce the itching effect after eating. Some Pacific Island people prefer to soak the taro in cold water before cooking to remove these irritating exudates (Bradbury and Nixon 1998). Colocasia leaves are cooked and eaten as vegetable and are said to contain B-carotene, iron and folic acid which protects against anaemia (FAO, 1990: Sukamoto, 2003)

\section{Materials and methods}

The colocasia leaves were purchased, cleaned and washed with water. For preparation of products with incorporation of fresh colocasia leaves, the leaves were boiled for $2 \mathrm{~min}$ in water and products were prepared. 4 recipes with 4 variations were prepared by fresh colocasia leaves. The basic recipe was prepared for each value added product.

Colocasia dhapata, colocasia masala vada were prepared with incorporation of fresh 
colocasia leaves. Five variations of each product were prepared for organoleptic evaluation. Variation one was basic recipe which was prepared without incorporation of fresh colocasia leaves and it served as control. Variations II to $\mathrm{V}$ were experimental variations with varying levels of incorporation of fresh colocasia leaves.

The organoleptic evaluation of prepared food products was conducted to find out the maximum level of incorporation of fresh colocasia in the selected food products (Amerine et al., 1965).

The sensory threshold test was carried out on 20 members to select panel members. Different solutions of sugar and salt with different concentrations for threshold test were prepared as described by Ranganna (1979) and the members were requested to evaluate the solutions for strength of different tastes. Considering the accuracy in evaluation of taste, 15 panel members were selected out of 20 to act as judges for sensory evaluation of products.

The selected food products were prepared with different levels of incorporation of fresh colocsia leaves. All the selected panel members were requested to evaluate the developed food products. The judges were requested to score the recipes for different sensory characters namely colour, texture, taste, flavour and overall acceptability by using Five Point Ranking Scale in which point 5 represent excellent, 4 represent very good, 3 represent good, 2 represent fair and 1 represent poor (Amerine et al., 1965). Highly accepted variations were selected for nutritional analysis and shelf life study.

The most accepted variation of all the selected food products was subjected to chemical analysis in the laboratory. Various parameters considered for nutrient analysis were moisture, protein, fat, total minerals, fibre, calcium, iron, zinc, magnesium and copper were estimated. The proximate composition was carried out as per procedures prescribed by A.O.A.C., (1984) method. Protein was estimated by macro kjeldhal method. Carbohydrate content was computed by Gopalan et al., (1989). The calcium was estimated by EDTA (Ethylene diamine tetra acetic acid) method. The trace elements, Iron, zinc, magnesium, and copper were estimated by atomic absorption spectrophotometer. The analysis was carried out by the sample moisture free.

The collected data was consolidated, tabulated and analysed statistically. The analysis of variance was used for interpreting the differences between different variations for individual sensory characters. The statistical difference with regard to nutrient content of developed products prepared with and without incorporation of fresh colocasia leaves was assessed by ' $t$ ' test (Gupta, 2014).

\section{Results and Discussion}

Colocasia dhapata prepared with various levels $(0,7,8,9$, and 10 per cent) of incorporation and without incorporation of fresh colocasia leaves, when subjected to organoleptic evaluation indicated that 10 per cent incorporation of colocasia leaves was well accepted (except texture) by panel members. The maximum score (4.8) for the overall acceptability was secured by 10 per cent level of incorporation of colocasia leaves in colocasia dhapata while the minimum score was 4.5 at 7 per cent level of incorporation of fresh colocasia leaves (Table 1).Incorporation of colocasaia leaves in dhapata, increased in calcium content (128.6 $\pm 1.35 \mathrm{mg})$ and magnesium $\quad(0.75 \pm 0.03 \mathrm{mg} / 100 \mathrm{gm})$ significantly. There was no significant difference increase in other nutrient content but numerically increased was seen in moisture, protein, fat, total mineral, fibre, carbohydrate, copper and zinc (Table 3 ). 
Table.1 Organolepticevaluation scores of colocasia dhapata

\begin{tabular}{|c|c|c|c|c|c|c|}
\hline Variations & $\begin{array}{c}\text { Level of colocasia leaves } \\
\text { incorporation (\%) }\end{array}$ & Colour & Texture & Taste & Flavour & $\begin{array}{c}\text { Overall } \\
\text { acceptability }\end{array}$ \\
\hline Basic & 0 & 4.5 & $\mathbf{5 . 0}$ & 4.6 & 4.7 & 4.5 \\
\hline I & 7 & 4.3 & 4.6 & 4.6 & 4.6 & 4.5 \\
\hline II & 8 & 4.4 & 4.6 & 4.6 & 4.6 & 4.6 \\
\hline III & 9 & 4.6 & 4.8 & 4.6 & 4.5 & $\mathbf{4 . 8}$ \\
\hline IV & $\mathbf{1 0}$ & $\mathbf{4 . 8}$ & 3.9 & $\mathbf{5 . 0}$ & $\mathbf{4 . 8}$ & $\mathbf{4 . 8}$ \\
\hline & CD & 0.2 & 0.2 & 0.2 & 0.1 & 0.1 \\
\hline & SE & 0.1 & 0.1 & 0.08 & 0.04 & 0.06 \\
\hline
\end{tabular}

NS: Non significant; *Significant at 5 per cent; **Significant at 1 per cent

Table.2 Organoleptic evaluation scores of colocasia masala wada

\begin{tabular}{|c|c|c|c|c|c|c|}
\hline Variations & $\begin{array}{c}\text { Level of colocasia leaves } \\
\text { incorporation (\%) }\end{array}$ & Colour & Texture & Taste & Flavour & $\begin{array}{c}\text { Overall } \\
\text { acceptability }\end{array}$ \\
\hline Basic & 0 & 4.7 & $\mathbf{4 . 9}$ & $\mathbf{4 . 7}$ & $\mathbf{4 . 8}$ & 4.5 \\
\hline I & 7 & 4.4 & 4.6 & 4.6 & 4.6 & 4.5 \\
\hline II & 8 & 4.4 & 4.6 & 4.6 & 4.6 & 4.6 \\
\hline III & 9 & $\mathbf{4 . 8}$ & 4.8 & 4.6 & 4.5 & $\mathbf{4 . 8}$ \\
\hline IV & $\mathbf{1 0}$ & $\mathbf{4 . 8}$ & 4.8 & 4.6 & $\mathbf{4 . 8}$ & $\mathbf{4 . 8}$ \\
\hline & CD & 0.3 & 0.2 & 0.1 & 0.2 & 0.2 \\
\hline & SE \pm & 0.1 & 0.08 & 0.05 & 0.07 & 0.08 \\
\hline
\end{tabular}

NS: Non significant; *Significant at 5 per cent; $* *$ Significant at 1 per cent

Table.3 Nutrient content of Colocasia dhapata (per 100g)

\begin{tabular}{|l|c|c|c|}
\hline \multirow{2}{*}{ Nutrients } & Basic & Accepted & \multirow{2}{*}{ 't' value } \\
\cline { 2 - 4 } & Mean \pm SD & Mean \pm SD & \\
\hline Moisture (g) & $20.61 \pm 0.98$ & $21.73 \pm 1.04$ & $1.10 \mathrm{NS}$ \\
\hline Protein (g) & $9.6 \pm 0.36$ & $11.0 \pm 1.0$ & $1.86 \mathrm{NS}$ \\
\hline Fat (g) & $6.55 \pm 0.05$ & $6.47 \pm 0.02$ & $0.22 \mathrm{NS}$ \\
\hline Total minerals (g) & $1.32 \pm 0.17$ & $1.45 \pm 0.3$ & $2.84 \mathrm{NS}$ \\
\hline Fibre (g) & $2.12 \pm 0.27$ & $2.70 \pm 0.1$ & $1.03 \mathrm{NS}$ \\
\hline Carbohydrates (g) & $78.99 \pm 0.10$ & $81.87 \pm 3.92$ & $10.52^{* *}$ \\
\hline Calcium (mg) & $107.5 \pm 2.5$ & $128.6 \pm 1.35$ & $1.55 \mathrm{NS}$ \\
\hline Iron (mg) & $3.98 \pm 0.005$ & $3.87 \pm 0.10$ & $0.48 \mathrm{NS}$ \\
\hline Copper (mg) & $1.28 \pm 0.02$ & $1.35 \pm 0.04$ & $2.82 \mathrm{NS}$ \\
\hline Zinc (mg) & $2.27 \pm 0.02$ & $2.31 \pm 0.001$ & $3.25^{*}$ \\
\hline Manganese (mg) & $0.68 \pm 0.005$ & $0.75 \pm 0.03$ & \\
\hline
\end{tabular}

NS: Non significant; *Significant at 5 per cent; **Significant at 1 per cent 
Table.4 Nutrient content of clocasia masala vada (per 100g)

\begin{tabular}{|c|c|c|c|}
\hline Nutrients & Basic & Accepted & \multirow{2}{*}{ 't' value } \\
\cline { 2 - 4 } & Mean \pm SD & Mean \pm SD & \\
\hline Moisture $(\mathrm{g})$ & $33.15 \pm 8.80$ & $34.92 \pm 8.59$ & $0.19 \mathrm{NS}$ \\
\hline Protein $(\mathrm{g})$ & $26.26 \pm 0.78$ & $28.00 \pm 1.00$ & $1.94 \mathrm{NS}$ \\
\hline Fat $(\mathrm{g})$ & $17.70 \pm 0.45$ & $18.15 \pm 0.00$ & $1.41 \mathrm{NS}$ \\
\hline Total minerals $(\mathrm{g})$ & $2.87 \pm 0.82$ & $2.97 \pm 0.07$ & $0.17 \mathrm{NS}$ \\
\hline Fibre (g) & $2.02 \pm 0.02$ & $2.42 \pm 0.07$ & $4.27^{*}$ \\
\hline Carbohydrates $(\mathrm{g})$ & $51.13 \pm 0.39$ & $45.25 \pm 5.25$ & $1.57 \mathrm{NS}$ \\
\hline Calcium $(\mathbf{m g})$ & $113.5 \pm 1.5$ & $135 \pm 4.5$ & $6.41^{* *}$ \\
\hline Iron $(\mathbf{m g})$ & $6.32 \pm 0.01$ & $6.45 \pm 0.17$ & $1.07 \mathrm{NS}$ \\
\hline Copper $(\mathbf{m g})$ & $1.35 \pm 0.005$ & $1.44 \pm 0.04$ & $3.15 \mathrm{NS}$ \\
\hline Zinc $(\mathbf{m g})$ & $1.02 \pm 0.005$ & $1.04 \pm 0.005$ & $4.0^{*}$ \\
\hline Manganese $(\mathbf{m g})$ & $1.07 \pm 0.025$ & $1.14 \pm 0.005$ & $4.80^{*}$ \\
\hline
\end{tabular}

NS: Non significant; *Significant at 5 per cent; **Significant at 1 per cent

Table.5 Mean scores for overall acceptability of colocasia dhapata stored in zip lock bag and aluminium foil for varying periods

\begin{tabular}{|c|c|c|c|}
\hline \multirow{2}{*}{$\begin{array}{c}\text { Storage period } \\
\text { (Days) }\end{array}$} & $\begin{array}{c}\text { Mean scores for overall acceptability for colocasia dhapata } \\
\text { Zip lock bag } \\
\text { Mean } \pm \text { SD }\end{array}$ & $\begin{array}{c}\text { Aluminium foil } \\
\text { Mean } \pm \text { SD }\end{array}$ & \multicolumn{2}{c|}{ ' $\mathrm{t}$ ' value } \\
\hline 1 & $4.66 \pm 0.48$ & $4.66 \pm 0.48$ & $0.00^{\mathrm{NS}}$ \\
\hline 2 & $4.13 \pm 0.35$ & $4.46 \pm 0.51$ & $2.64 \mathrm{NS}$ \\
\hline 3 & $3.66 \pm 0.48$ & $3.73 \pm 0.70$ & $0.36^{\mathrm{NS}}$ \\
\hline 4 & $3.06 \pm 0.45$ & $3.33 \pm 0.48$ & $1.46^{\mathrm{NS}}$ \\
\hline CD & 0.330 & 0.408 & \\
\hline SE \pm & 0.116 & 0.144 & \\
\hline F- value & $34.3^{* *}$ & $18.86^{* *}$ & \\
\hline
\end{tabular}

NS: Non significant

Table.6 Mean scores for overall acceptability of colocasia masala vada stored in zip lock bag and aluminium foil for varying periods

\begin{tabular}{|c|c|c|c|}
\hline \multirow{2}{*}{$\begin{array}{l}\text { Storage } \\
\text { period } \\
\text { (Days) }\end{array}$} & \multicolumn{2}{|c|}{$\begin{array}{l}\text { Mean scores for overall acceptability for } \\
\text { colocasia masala vada }\end{array}$} & \multirow[t]{2}{*}{ 't' value } \\
\hline & $\begin{array}{c}\text { Zip lock bag } \\
\text { Mean } \pm \text { SD }\end{array}$ & $\begin{array}{l}\text { Aluminium foil } \\
\text { Mean } \pm \text { SD }\end{array}$ & \\
\hline 1 & $5.00 \pm 0.00$ & $5.00 \pm 0.00$ & $0.000^{\mathrm{NS}}$ \\
\hline 2 & $4.73 \pm 0.45$ & $4.86 \pm 0.35$ & $1.000^{\mathrm{NS}}$ \\
\hline 3 & $3.26 \pm 0.45$ & $3.73 \pm 0.70$ & $1.704^{\mathrm{NS}}$ \\
\hline $\mathbf{C D}$ & 0.276 & 0.336 & \\
\hline $\mathrm{SE} \pm$ & 0.096 & 0.117 & \\
\hline F- value & $93.54 * *$ & $32.21 * *$ & \\
\hline
\end{tabular}

NS: Non significant 
Colocasia dhapata was stored in zip lock bag and aluminium foil for 4 days. The sensory evaluation for overall acceptability was carried out daily. Results indicated that the scores recorded for the dhapata at initial stage in both storage packs were $4.66 \pm 0.48$. The sensory scores for overall acceptability decreased from second day. More decrease was seen in the product kept in zip lock bag. Though there was decrease in the sensory scores for overall acceptability the samples were well accepted and acquired good category scores up to 4 days of storage in both the pouches (Table 5).

Organoleptic evaluation of colocasia masala vada with $0,7,8,9$ and 10 per cent level of incorporation of fresh colocasia leaves and without addition of colocasia leaves indicated that colocasia masala vada with 10 per cent of fresh colocasia leaves obtained highest scores. The highest scores of 4.8 for overall acceptability was recorded by colocasia masala wada prepared with 9 and 10 per cent level of incorporation of fresh colocasia leaves (Table 2). Masala vada with addition of colocasia leaves showed significant increase in values of nutrients such as fibre $2.42 \pm 0.07 \mathrm{~g}$ calcium $135 \pm 4.5 \mathrm{mg}$, zinc 1.04 $\pm 0.005 \mathrm{mg}$, manganese $1.14 \pm 0.005 \mathrm{mg}$ $1100 \mathrm{~g}$. Other nutrients were numerically increased (Table 4). Colocasia masala vada was stored in zip lock bag and aluminium foil for 3 days. The effect of storage period was non significantly noticed on overall acceptability of colocasia masala vada stored in zip lock bag and aluminium foil pouches, but overall acceptability score was decreasing in both the samples as the period of storage was increasing (Table 6).

It is concluded from this study that fresh colocasia leaves can be incorporated up to 10 per cent. Colocasia leaves are rich in calcium so the calcium content of the products will be increased and will be useful to combat calcium deficiency. Colocasia leaves are also rich in minerals like iron, copper, zinc and manganese, so the addition of colocasia leaves will be helpful to cure micronutrient deficiencies.

\section{References}

A.O.A.C. (1984). Official methods of analysis. Association of Official Analytical Chemist. $14^{\text {th }} \quad$ Ed. Washington DC.

Amerine, M. A., Pongborn R.M. and Roessler E.D. (1965). Principles of sensory evaluation of foods. Academic Press, New York.

Anju Rani, Gupta, A., and Chopra, N., (2017). Organoleptic Evaluation of Dried Arbi Leaf (Colocasia esculenta) Powder Incorporated in Gattekisabji and Mathari. Int. J. Pure App. Biosci.5 (4), 635-640.

Bradbury JH, Nixon RW. (1998). The acridity of raphides from the edible aroids. J Sci Food Agric 76: 608-616.

FAO (1990). Roots Tubers, Plantation and Banana in Human Nutrition. Effect of Processing on Nutritive Values. Food and Agricultural Organization of The United Nations, Rome, Italy.

Gopalan, C., Rama Sastri, B. V. R, and Balsubramaniam, S. C. (1989). Nutritive value of Indian foods, National Institute of Nutrition (ICMR) Hyderabad, pp, 49.

Gupta S.P. (2014). Statistical Methods. Sultan Chand and Son Publication.

Kaushal, M., Sharma, K. D. and Attri, S. (2013). Effect of blanching on nutritional quality of dehydrated colocasia leaves. Indian Journal of Natural Products and Research, Vol.4 (2), 161-164.

Noonia S. Savage G. P. (1999) Oxalate content of Food and its Effects on 
Humans. Asian Pacific J. Clin. Nutr. 8 (1): 64-74.

Odedeji, J. O., Oyeleke, G. O., Ayinde, L. A. and Azeez, L. A. (2014). Nutritional, Antinutritional Compositions and Organoleptic Analyses of Raw and Blanched Cocoyam (Colocasia esculenta) Leaves. Journal of Environmental Science, Toxicology and Food Technology (IOSR-JESTFT). Volume 8, Issue 2 Ver. II, PP 45-48.

Oscarsson, K.V. and Savage, G. P. (2007). Composition and availability of soluble and insoluble oxalates in raw and cooked taro (Colocasia esculenta var var. Schott) leaves. Food chemistry, Volume 101, 559-562.
Ranganna S. (1979). Titrable acidity. In: Ranganna, S. (Ed). Manual of Analysis of Fruit and Vegetable products. Pp. 78. Tata McGraw Hill Publishing Company Ltd., New Delhi, India

Sukamoto L. A. (2003) Developing of Easily Maturing and leaf Bright Resistant Cocoyam (Colocasia esculenta (L) Scott) with Improved Taste. Proceedings of a Final Coordination Meeting Organized by the Joint FAO/IAEA Division of Nuclea Techniques in Food and Agriculture Held in Pretoria, South Africa. 33:267284.

\section{How to cite this article:}

Pratibha Thombare and Farooqui H. Farzana. 2018. Development of Value Added Food Products with Incorporation of Colocasia Leaves (Colocasia esculenta). Int.J.Curr.Microbiol.App.Sci. 7(11): 2851-2857. doi: https://doi.org/10.20546/ijcmas.2018.711.328 